\title{
Erythropoietin and erythropoietin receptor expression in human prostate cancer
}

\author{
Murat O Arcasoy ${ }^{1,4}$, Khalid Amin ${ }^{2}$, Robin T Vollmer ${ }^{3,4}$, Xiaohong Jiang ${ }^{1}$, \\ Wendy Demark-Wahnefried ${ }^{5}$ and Zishan A Haroon ${ }^{1}$ \\ ${ }^{1}$ Department of Medicine, Duke University Medical Center, Durham, NC, USA; ${ }^{2}$ Biosciences Division, SRI \\ International, Menlo Park, CA, USA; ${ }^{3}$ Department of Pathology, Duke University Medical Center, Durham, \\ NC, USA; ${ }^{4}$ Veterans Administration Medical Center, Durham, NC, USA and ${ }^{5}$ Department of Surgery, Duke \\ University Medical Center, Durham, NC, USA
}

\begin{abstract}
Erythropoietin is a hematopoietic cytokine that regulates the production of red blood cells. Erythropoietin is normally produced in the adult kidney in a hypoxia-inducible manner. The recombinant form of human erythropoietin is in clinical use for the prevention and treatment of anemia that is associated with cancer and its treatment with chemoradiation therapy. A series of recent studies from our laboratory and others have reported the expression of receptors for erythropoietin in several different types of human cancer cells. In the present study, we investigated the expression of erythropoietin receptor and its ligand erythropoietin in human prostate cancer. In clinical specimens of prostate cancer, we found abundant expression of erythropoietin receptor protein in all primary tumors examined using immunohistochemistry. Furthermore, we observed erythropoietin coexpression in prostate cancer cells by immunohistochemical analysis. To determine whether monolayer cultures of continuous cell lines derived from prostate cancer also express erythropoietin receptor and erythropoietin, we studied well-characterized hormone-responsive (LNCaP) and hormone-refractory (PC-3) prostate cancer cell lines. We performed reverse-transcription and polymerase chain reaction assays to detect erythropoietin receptor and erythropoietin mRNA transcripts, and also immunoprecipitation and immunoblotting to detect erythropoietin receptor protein expression in prostate cancer cells. These experiments revealed the expression of both erythropoietin receptor and erythropoietin in LNCaP and PC-3 cells suggesting that these prostate cancer cell lines may serve as useful experimental models for further studies of erythropoietin and erythropoietin receptor function in prostate cancer. The coexpression of erythropoietin receptor and its ligand erythropoietin in human prostate cancer cells suggests the potential for growth regulation by erythropoietin-erythropoietin receptor in an autocrine or paracrine manner.
\end{abstract}

Modern Pathology (2005) 18, 421-430, advance online publication, 1 October 2004; doi:10.1038/modpathol.3800288

Keywords: erythropoietin; erythropoietin receptor; prostate cancer

Erythropoietin is a glycoprotein hormone that is the principal regulator of red blood cell production in mammals. ${ }^{1}$ The primary sites of physiologic, hypoxia-inducible erythropoietin production include the fetal liver and adult kidney. ${ }^{2}$ The ability of the recombinant form of human erythropoietin to stimulate the production of red blood cells has led to its widespread clinical use in patients with various chronic diseases that are associated with anemia, such as cancer. ${ }^{3}$ The biologic effects of the

Correspondence: Dr MO Arcasoy, MD, FACP, Department of Medicine, Divisions of Hematology and Medical Oncology, Duke University School of Medicine, DUMC Box 3912, Durham, NC 27710, USA.

E-mail: arcas001@mc.duke.edu

Received 14 May 2004; revised and accepted 29 July 2004; published online 1 October 2004 hematopoietic cytokine erythropoietin require its binding to its specific transmembrane receptor erythropoietin receptor expressed in erythroid cells. ${ }^{4-6}$ The interaction of erythropoietin with its cell surface receptor induces a conformational change of receptor homodimers leading to the activation of intracellular signal transduction that mediates the ability of erythropoietin to support the proliferation, terminal differentiation and survival of erythroid cells. ${ }^{7,8}$

Several previous studies have provided evidence for the presence of a functional erythropoietinerythropoietin receptor system in nonhematopoietic cell types and organs. For instance, the expression of erythropoietin receptor in vascular endothelial cells and neurons is associated with diverse physiological effects of erythropoietin that are distinct from its regulatory function in erythropoiesis. ${ }^{9-11}$ In the 
brain where neurons express erythropoietin receptor and astrocytes express erythropoietin in a hypoxiainducible manner, erythropoietin was shown to protect against neuronal injury associated with ischemia. ${ }^{12-15}$ In the uterus, erythropoietin-erythropoietin receptor function was shown to be involved in the regulation of cyclic uterine angiogenesis. ${ }^{16} \mathrm{In}$ another example of the diverse nonhematopoietic biological effects of erythropoietin-erythropoietin receptor, our recent studies have shown that erythropoietin is a cytokine that promotes angiogenesis and modulates the physiologic wound-healing cascade. ${ }^{17}$

A series of recent reports have described the expression of erythropoietin receptor and erythropoietin in several different types of human cancer cells. ${ }^{18-20}$ In the present study, our objective was to determine whether human prostate cancer cells express the erythropoietin receptor and its ligand erythropoietin. We examined clinical specimens of primary prostate cancer for expression of erythropoietin receptor and erythropoietin protein using immunohistochemistry. We also investigated the relationship between erythropoietin receptor and erythropoietin expression and tumor growth fraction and apoptosis indices. In addition, we explored erythropoietin receptor and erythropoietin expression in monolayer cultures of continuous prostate cancer cell lines to determine whether these cell lines may be useful for future studies of erythropoietinerythropoietin receptor biology in prostate cancer.

\section{Materials and methods}

\section{Clinical Specimens of Prostate Cancer}

Human prostate cancer specimens were obtained under a protocol approved by the Institutional
Review Board at Duke University Medical Center. Samples came from a cohort of 18 previously untreated patients with an age range of 53-75 years old who underwent radical prostatectomy for prostatic adenocarcinoma between 1995 and 2000. Tumors were graded according to the Gleason method (by RTV) as illustrated in Table 1. The prostate-specific antigen (PSA) level at diagnosis ranged from 4.7 to $20.1 \mathrm{ng} / \mathrm{ml}$. Formalin-fixed paraffin-embedded tissue blocks were obtained from the archives for immunohistochemical studies.

\section{Cell Cultures}

Monolayer cultures of human cancer cells derived from cancer of the prostate (LNCaP and PC-3 cells) were obtained from American Type Culture Collection (ATCC) and maintained in cell culture at $37^{\circ} \mathrm{C}$ in a humidified $5 \% \mathrm{CO}_{2}$ atmosphere in accordance with the instructions from ATCC (Rockville, MD, USA). Chinese hamster ovary (CHO) cells engineered to overexpress human erythropoietin receptor were described previously. ${ }^{20}$

\section{Immunohistochemistry}

Sections ( $4 \mu \mathrm{m}$ in thickness) from each block were placed on glass slides. The primary antibodies used in immunohistochemical studies were:

- Polyclonal, affinity purified, rabbit anti-human erythropoietin receptor antibody at a dilution of 1:50 (C-20, Santa Cruz Biotechnology, Santa Cruz, CA, USA).

- Polyclonal, affinity purified, rabbit antierythropoietin antibody at dilution 1:50 (H-162, Santa Cruz).

Table 1 Degree of EPOR and EPO staining on 18 prostate cancer specimens examined ${ }^{\text {a }}$

\begin{tabular}{|c|c|c|c|c|c|c|c|c|}
\hline Tumor no & Gleason score & PSA ng/ml & EPOR tumor & EPOR benign & EPO tumor & EPO benign & $M I B-1$ & TUNEL \\
\hline 1 & $3+4$ & 7.2 & 2.9 & 1.2 & 2.75 & 1.15 & 2.6 & 0 \\
\hline 2 & $3+4$ & 7.6 & 2.8 & 2.4 & 1.8 & 1.4 & 9 & 2 \\
\hline 3 & $4+3$ & 8.4 & 2.95 & 2 & 1.3 & 1.2 & 5 & 1 \\
\hline 4 & $2+3$ & 4.7 & 2.8 & 1.6 & 1.3 & 1.6 & 7.5 & 0 \\
\hline 5 & $3+3$ & 8.9 & 2.4 & 2.3 & 2.3 & 2.35 & 3 & 0 \\
\hline 6 & $4+3$ & 9.5 & 1.6 & 1.4 & 1.3 & 0.95 & 20 & 2 \\
\hline 7 & $5+4$ & 8.1 & 2.9 & 2.6 & 2.7 & 1.9 & 2.8 & 0 \\
\hline 8 & $3+3$ & 5.9 & 2.5 & 2.3 & 2.3 & 1.5 & 6.8 & 0 \\
\hline 9 & $3+3$ & 18.6 & 1.5 & 2.1 & 0.40 & 1 & 1.1 & 1 \\
\hline 10 & $4+4$ & 20.1 & 2.3 & 1.8 & 1.2 & 0.80 & 6.8 & 1 \\
\hline 11 & $3+4$ & 20 & 2.7 & 1.8 & 1.95 & 1.4 & 38 & 1 \\
\hline 12 & $3+4$ & 12.8 & 2.6 & 2.6 & 2.6 & 2.5 & 0.9 & 2 \\
\hline 13 & $3+3$ & 7 & 2.8 & 2 & 1.4 & 1.4 & 0.52 & 2 \\
\hline 14 & $3+3$ & 16.4 & 1.95 & 2.3 & 1 & 2.1 & 6.1 & 0 \\
\hline 15 & $3+4$ & 10 & 2.2 & 2.2 & 2.1 & 1.9 & 1.1 & 1 \\
\hline 16 & $3+4$ & 5 & 2.3 & 1.9 & 2.4 & 1.6 & 1.6 & 2 \\
\hline 17 & $3+4$ & 7.3 & 2.7 & 2.2 & 2.3 & 1.6 & 1.9 & 2 \\
\hline 18 & $3+4$ & 11.2 & 2.5 & 1.5 & 1.6 & 0.85 & 9 & 2 \\
\hline
\end{tabular}

${ }^{\mathrm{a}}$ Weighted mean of stain intensity for EPO or EPOR was determined as described in Materials and methods to reflect both the percentage and the intensity of tumor cells or adjacent benign glands exhibiting immunoreactivity. 
- Monoclonal MIB-1 antibody at a dilution of 1:200 (Biocare, Walnut Creek, CA, USA).

Both the antierythropoietin and antierythropoietin receptor antibodies have been validated previously and immunohistochemistry was carried-out as described..$^{19,21,22}$ For erythropoietin and erythropoietin receptor staining, the sections were deparaffinized in Hemo-D, rehydrated in graded alcohols, subjected to endogenous peroxidase block in $3 \% \mathrm{H}_{2} \mathrm{O}_{2}$ and boiled in $10 \%$ citrate buffer for antigen retrieval. This was followed by blocking with $5 \%$ donkey serum (Jackson Immunoresearch Labs, West Grove, PA, USA). Slides were incubated with antierythropoietin receptor or antierythropoietin antibodies overnight at $4{ }^{\circ} \mathrm{C}$, and then washed and incubated with biotinylated donkey anti-rabbit secondary antibodies (Jackson labs, $1: 1000$ ) at $37^{\circ} \mathrm{C}$ for $25 \mathrm{~min}$ followed by another incubation for $25 \mathrm{~min}$ with avidin-biotin peroxidase complex (ABC Kit, Vector Labs, Burlingame, CA, USA). Finally the sections were developed with diaminobenzidine tetrahydrochloride (DAB) chromogen and counterstained with hematoxylin. Negative controls for the immunohistochemistry consisted of sections incubated with preimmune rabbit immunoglobulin and were negative for any reactivity. Cytoplasmic or membrane staining was considered positive and for each neoplasm both the percentage of cells that exhibited immunoreactivity as well as the intensity of the staining in tumor cells were taken into account by evaluating pathologist (KA). The percentage of tumor cells that exhibited no staining (0) or weak (1), moderate (2) or intense staining (3) was determined by microscopic examination and the immunoreactivity score was determined by calculating weighted mean of stain intensity using the following formula:

Weighted mean of stain intensity

$$
=\frac{\sum \text { Intensity } \times \text { Percentage of cells }}{\text { Total percentage of cells }}
$$

for a maximum weighted mean staining intensity score of 3.00 .

MIB-1 labeling index was used as a marker of tumor growth fraction using an antibody from the murine MIB-1 hybridoma clone and the labeled streptavidin/biotin/peroxidase/diaminobenzidine tetrachloride (DAB) method (Biocare, Walnut Creek, CA, USA) with antigen retrieval by pressure-cooking in citrate buffer (DAKO, Inc., Carpinteria, CA, USA). Slides were counterstained with hematoxylin and tonsillar tissue (lymphoid hyperplasia) served as a control. For each tumor, percent of positive nuclei in at least 10 random high-power fields (mean of 400 cells per tumor) were counted, averaged and recorded as described previously. ${ }^{23}$

Apoptotic indices were determined using the TUNEL method (TdT-FragEL ${ }^{\mathrm{TM}}$ kit, Oncogene, Boston, MA, USA). Pretreated slides were incubated in biotin-labeled/unlabeled deoxynucleotides containing $\mathrm{TdT}$ at $37^{\circ} \mathrm{C}$ for $1.5 \mathrm{~h}$. The biotinylated nucleotides were detected using a streptavidinhorseradish peroxidase conjugate and then reacted with diaminobenzidine, forming an insoluble brown-colored precipitate at the site of DNA fragmentation. Using light microscopy and assessing the degree of nuclear staining against a methyl green counterstain, slides were given a rank score of 0 (lowest apoptotic index), 1 or 2 (highest apoptotic index).

\section{RNA Isolation, Analysis and Southern Blotting}

We investigated for erythropoietin receptor expression in monolayer cultures of cancer cell lines derived from human prostate cancer. The availability of continuous cell lines that express erythropoietin receptor may facilitate further molecular and functional studies of erythropoietin receptor expression in prostate cancer using in vitro as well as in vivo experimental models. We used well-characterized prostate cancer cell lines including androgenresponsive (LNCaP) cells and androgen-refractory (PC-3) cell lines. Using total RNA isolated from the cells, we performed reverse transcription and polymerase chain reaction assays designed to detect erythropoietin receptor mRNA transcripts using oligonucleotide primers specific for the coding sequence of human erythropoietin receptor gene. Total RNA was isolated using the RNeasy kit from Qiagen (Valencia, CA, USA) according to the manufacturer's instructions. To eliminate residual genomic DNA, the RNA samples were subjected to Amplification Grade DNase I digestion (Invitrogen, Carlsbad, CA, USA). For erythropoietin receptor mRNA transcript expression, complementary DNA (cDNA) was synthesized using $2 \mu \mathrm{g}$ total RNA in a $20 \mu \mathrm{l}$ reaction containing $500 \mathrm{ng}$ oligodT primer, $1 \mathrm{mM}$ each dNTPs, $40 \mathrm{U}$ RNase inhibitor, $20 \mathrm{mM}$ Tris-HCl (pH 8.4), $50 \mathrm{mM} \mathrm{KCl,} 10 \mathrm{mM}$ DTT, $5 \mathrm{mM}$ $\mathrm{MgCl}_{2}$ and $50 \mathrm{U}$ of Superscript II reverse transcriptase (Invitrogen). Negative control reactions were performed in which RNA but no reverse transcriptase was added. Following first-strand cDNA synthesis, RNase $\mathrm{H}$ digestion (Invitrogen) was carried out prior to PCR. For PCR amplification, $1 \mu \mathrm{l}$ of cDNA was used in a $50 \mu \mathrm{l}$ reaction containing $10 \mathrm{mM}$ Tris$\mathrm{HCl}, 1.5 \mathrm{mM} \mathrm{MgCl}_{2}, 50 \mathrm{mM} \mathrm{KCl}(\mathrm{pH} 8.3), 200 \mu \mathrm{M}$ each dNTP and $1 \mathrm{U}$ Taq DNA polymerase (Roche) with $0.4 \mu \mathrm{M}$ of each oligonucleotide primer-sense $5^{\prime}$ GCT GTA TCA TGG ACC ACC TC $3^{\prime}$ and antisense $5^{\prime}$ GGT AGG AGA AGC TGT AGT TG $3^{\prime}$. PCR was performed using Thermal Cycler PTC-100 (MJ Research, Waltham, MA, USA). In each PCR experiment, following an initial incubation at $95^{\circ} \mathrm{C}$ for $2 \mathrm{~min}$, the denaturation step was performed at $94^{\circ} \mathrm{C}$ for $1 \mathrm{~min}$, annealing step at $60^{\circ} \mathrm{C}$ for $1 \mathrm{~min}$ and the extension step was at $72^{\circ} \mathrm{C}$ for 1 min for 40 cycles. An extension step was performed at $72^{\circ} \mathrm{C}$ for $10 \mathrm{~min}$ 
after the final PCR cycle. In each PCR experiment, a negative control reaction was performed with water. Positive control for erythropoietin receptor expression included using cDNA synthesized from RNA from primary human erythroblasts as described. ${ }^{20}$ To detect erythropoietin mRNA transcript expression, we used $2 \mu \mathrm{g}$ of total RNA using the OneStep reverse transcription-polymerase chain reaction kit with Qsolution (Qiagen) according to the manufacturer's instructions and $0.6 \mu \mathrm{M}$ of each oligonucleotide primer-sense $5^{\prime}$ ATC ACG ACG GGC TGT GCT GAA CAC $3^{\prime}$ and anti-sense $5^{\prime}$ GGG AGA TGG CTT CCT TCT GGG CTC $3^{\prime}$ with sequential incubations at $50^{\circ} \mathrm{C}$ for $30 \mathrm{~min}$ and $95^{\circ} \mathrm{C}$ for $15 \mathrm{~min}$, followed by PCR performed at $94^{\circ} \mathrm{C}$ for $1 \mathrm{~min}$, annealing step at $60^{\circ} \mathrm{C}$ for $1 \mathrm{~min}$ and extension step was at $72^{\circ} \mathrm{C}$ for $1 \mathrm{~min}$ for 40 cycles. The PCR products were separated in $1.8 \%$ agarose gels, and the specificity of the amplified PCR products was confirmed by Southern blot analysis by hybridization of the blots to a radiolabeled human erythropoietin receptor or erythropoietin cDNA probes as described. ${ }^{20}$

\section{Immunoprecipitation and Immunoblotting}

To prepare whole cell lysates, monolayer cultures of prostate cancer cells were grown to confluence in $10 \mathrm{~cm}$ tissue culture plates, washed twice with icecold phosphate-buffered saline and lysed in ice-cold buffer containing $20 \mathrm{mM}$ Tris-HCl (pH 7.4), $150 \mathrm{mM}$ $\mathrm{NaCl}, 10 \%$ glycerol, $5 \mathrm{mM}$ EDTA, $10 \mathrm{mM} \mathrm{NaF}, 1 \%$ Triton X-100 supplemented with $1 \mathrm{mM} \mathrm{Na} \mathrm{VO}_{4}$, $1 \mathrm{mM}$ phenylmethylsulfonylfluoride, $10 \mu \mathrm{g} / \mathrm{ml}$ aprotinin and $10 \mu \mathrm{g} / \mathrm{ml}$ leupeptin followed by centrifugation at $13000 \mathrm{~g}$ for $20 \mathrm{~min}$ at $4^{\circ} \mathrm{C}$. The concentration of the soluble proteins in the supernatants was determined using Bio-Rad protein assay (Hercules, CA, USA). Immunoprecipitation using $2 \mu \mathrm{g}$ rabbit polyclonal antihuman erythropoietin receptor antibody (Santa Cruz) was performed as described. ${ }^{20}$ The immune complexes were collected by incubation with protein A-agarose beads (Roche, Indianapolis, IN, USA), washed four times in cell lysis buffer supplemented with fresh protease inhibitors, eluted by heating to $95^{\circ} \mathrm{C}$ for $5 \mathrm{~min}$ in 2X Laemmli sample buffer and subjected to $8 \%$ sodium dodecylsulfate polyacrylamide gel electrophoresis (SDS-PAGE). The separated proteins were electrophoretically transferred to PVDF (Immobilon-
P) membranes (Millipore, Bedford, MA, USA). The membranes were blocked in TBST (10 mM Tris-HCl ( $\mathrm{pH}$ 7.4), $150 \mathrm{mM} \mathrm{NaCl}, 0.05 \%$ (v/v) Tween-20) containing $5 \%$ nonfat dry milk for $1-2 \mathrm{~h}$ with agitation at room temperature. Immunoblots were then incubated with primary antibody (C-20$1: 1000)$ overnight in $4^{\circ} \mathrm{C}$ with gentle rocking. Following a second incubation with horseradishperoxidase conjugated donkey anti-rabbit secondary antibodies (Pierce, Rockford, IL, USA), the immune complexes were detected using SuperSignal Chemiluminescent Substrate (Pierce) and visualized with autoradiography following a $2-5 \mathrm{~min}$ exposure to Kodak Biomax MR film.

\section{Statistical Analyses}

Linear regression was used to relate either erythropoietin receptor score or erythropoietin score to other variables, and the residuals were examined to determine that they were approximately normally distributed. Paired $t$-tests were used to compare scoring results in benign vs tumor glands. The analyses were performed using S-PLUS software MathSoft, Inc. (Seattle, WA, USA) and all $P$-values are for two-tailed tests with a significance level set at $P<0.05$.

\section{Results}

\section{Erythropoietin and Erythropoietin Receptor are Expressed in Clinical Specimens of Prostate Cancer}

Immunohistochemical staining of the prostate tumors was performed to investigate for erythropoietin and erythropoietin receptor expression. Representative photomicrographs are illustrated in Figure 1 and the immunohistochemistry data are summarized in Table 1. Erythropoietin and erythropoietin receptor expression was observed in all samples analyzed in the study. Glandular epithelium in both tumor tissue and adjacent normal epithelium showed positive immunostaining for erythropoietin receptor (Figure 1, panels a-d) and erythropoietin (Figure 1, panels e-h). A predominantly cytoplasmic pattern of staining for both erythropoietin and erythropoietin receptor was present in cancer cells, consistent with the immunoreactivity pattern that we and others have observed in other types of

\footnotetext{
Figure 1 Erythropoietin and erythropoietin receptor expression in clinical specimens of prostate cancer. Immunohistochemical stain of prostate cancer sections with erythropoietin receptor (panels a-d) and erythropoietin (panels $\mathbf{e}-\mathbf{h}$ ) antibodies illustrating four tumors of varying differentiation exhibiting immunoreactivity for both erythropoietin receptor and erythropoietin in cancer cells in contiguous sections. Panels (a) and (e) Prostate adenocarcinoma (Gleason grade 3) at low magnification $\times 200$ illustrating erythropoietin receptor and erythropoietin expression in neoplastic glands. Panels (b-f) and (c-g) Two prostate neoplasms illustrating adenocarcinomas (b-f) Gleason grade 3; (c-g) Gleason grade 3 (at top) and grade 4 (at bottom) exhibiting intense immunoreactivity for both erythropoietin receptor (panels b, c) and erythropoietin (panels $\mathbf{f}, \mathbf{g})$ in neoplastic prostate glands $(\times 400)$. Adjacent benign epithelium exhibits weaker immunoreactivity for erythropoietin receptor and erythropoietin in both tumors. Panels (d) and (h) Prostatic adenocarcinoma (Gleason grade 4) exhibiting strong erythropoietin receptor immunoreactivity (panel d). Intensity of erythropoietin staining (panel h) is weak to moderate in the tumor cells $(\times 200)$.
} 
EPO R
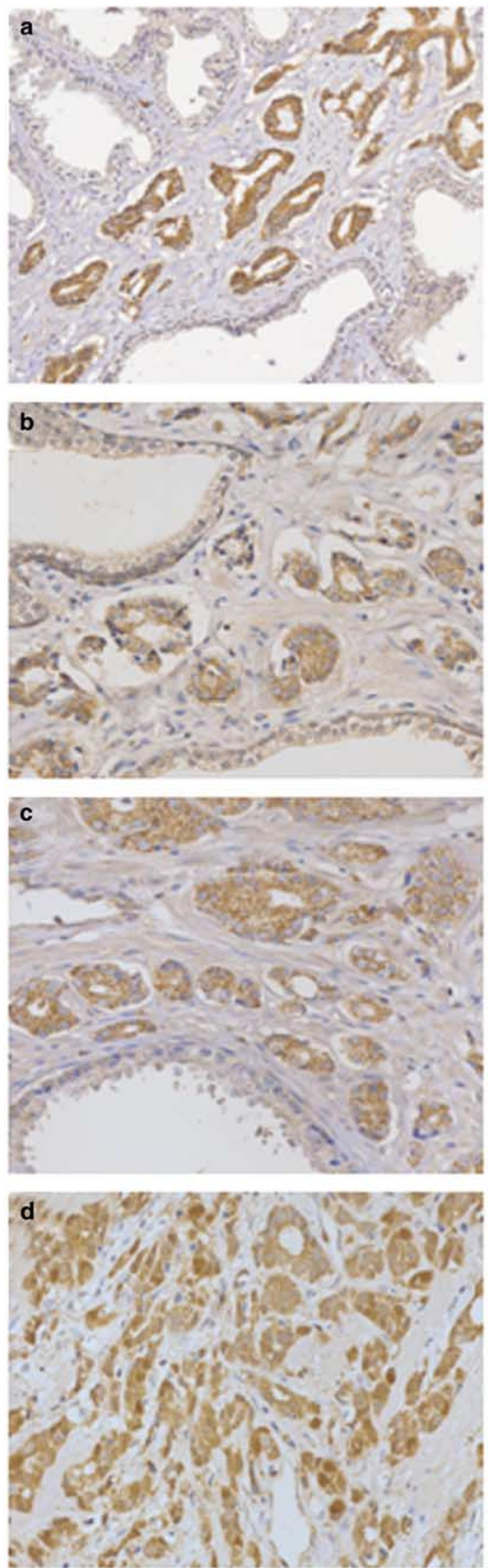

\section{EPO}
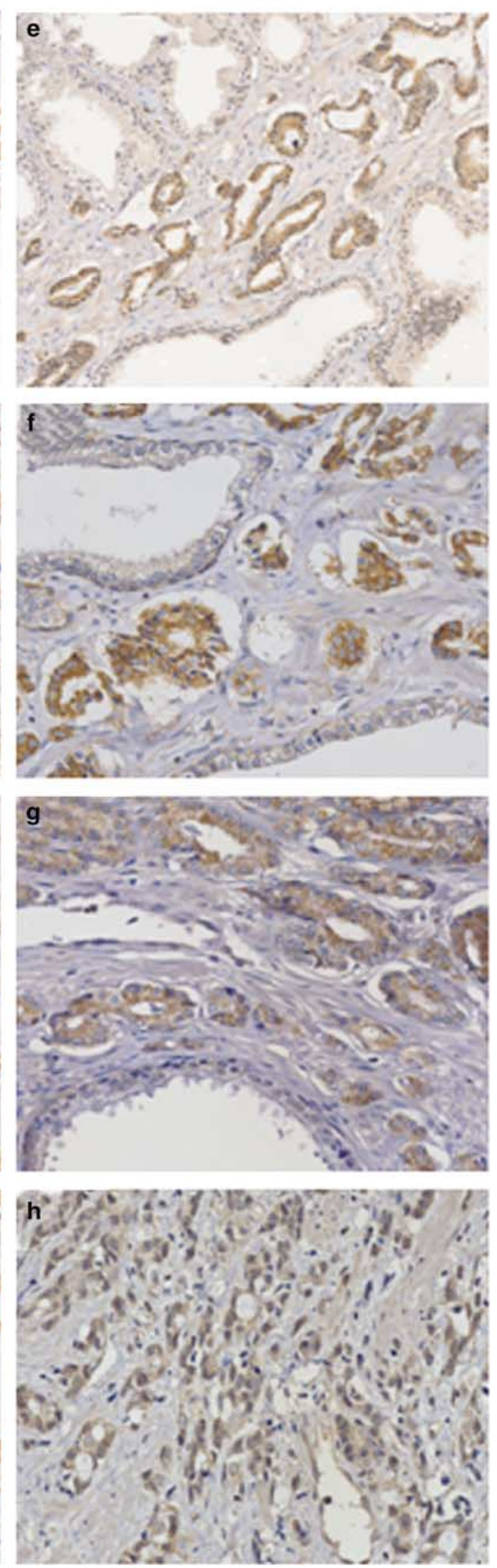
neoplasms that express erythropoietin and erythropoietin receptor. ${ }^{18,19,24,25}$ Erythropoietin receptor also showed membrane immunoreactivity in some of the neoplastic and host cells. In most of the sections, the intensely erythropoietin receptor stained neoplastic glands could clearly be identified infiltrating into their weakly reactive non-neoplastic counterparts. Most of the tumors exhibited moderate to intense erythropoietin receptor immunoreactivity (Figure 1, panels a-d and Table 1). Erythropoietin receptor immunoreactivity also was observed in certain other cell types, most notably the endothelial cells of larger blood vessels and particularly the tumor macrophages which were strongly positive (not shown). Erythropoietin immunoreactivity was present in all tumors (Figure 1, panels $\mathrm{e}-\mathrm{h}$ and Table 1) and the adjacent normal or hyperplastic prostatic glands also exhibited expression of erythropoietin.

We performed statistical analyses to relate erythropoietin and erythropoietin receptor expression in prostate tumors to other parameters including cellular proliferation and apoptosis indices as determined by MIB-1 staining and TUNEL assays, respectively (Table 1). In benign glands, the erythropoietin receptor score was significantly related to erythropoietin score in benign glands $(P=0.0015$ by linear regression). The erythropoietin receptor score in tumor showed similar significant association with the erythropoietin score in tumor $(P=0.02$ by linear regression). Interestingly, the erythropoietin receptor score in tumor was not significantly related to the additional variables of either erythropoietin or erythropoietin receptor in benign tissues $(P>0.5$ by linear regression). In addition, both expression of erythropoietin receptor and erythropoietin was significantly higher in tumor glands than in benign glands $(P=0.0033$ and 0.048 , respectively by $t$-test). In summary, the data indicate that erythropoietin receptor and erythropoietin are upregulated by tumor and are closely linked when considering the same tissue type, that is, benign or tumor glands, but there is no apparent linkage between benign and malignant glands with respect to either marker. There was no association between serum PSA and any of the erythropoietin receptor or erythropoietin scores ( $P>0.03$ by linear regression). Furthermore, there was no association between tumor erythropoietin receptor or erythropoietin and MIB-1 index, TUNEL apoptosis category or Gleason score in the tumor $(P>0.1$ by linear regression).

\section{Human Prostate Cancer Cell Lines Express Erythropoietin Receptor and Erythropoietin}

As illustrated in Figure 2b, we found erythropoietin receptor mRNA transcript expression in both $\mathrm{LNCaP}$ and PC-3 cells. We then investigated for the expression of erythropoietin receptor protein in
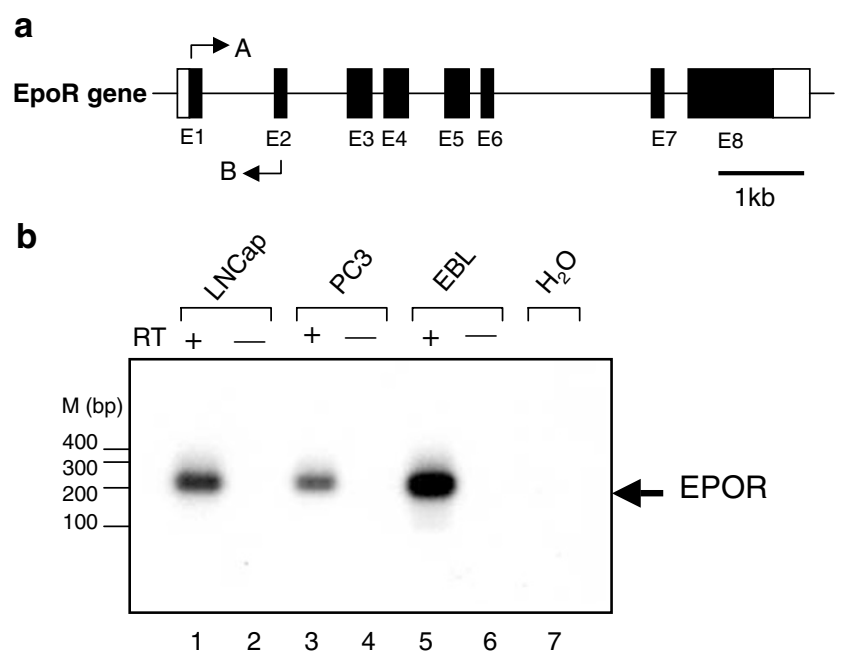

Figure 2 Expression of erythropoietin receptor transcripts in monolayer cultures of prostate cancer cell lines. (a) The exonintron structure of the erythropoietin receptor gene is shown. The relative positions of the PCR primers A (sense) and B (antisense) are indicated in exons 1 and 2, respectively. (b) reverse transcription-polymerase chain reaction was performed using RNA from monolayer cultures of cancer cell lines derived from prostate cancer LNCaP and PC-3 (lanes 1 and 3). Negative controls included reverse transcription-polymerase chain reaction without reverse transcriptase in the reactions (reverse transcriptase -, lanes $2,4,6)$, PCR using water $\left(\mathrm{H}_{2} \mathrm{O}\right.$, lane 7$)$ that did not yield amplification products. Positive control was reverse transcription-polymerase chain reaction using RNA from primary human erythroblasts (erythroblast, lane 5). The PCR amplification products were separated in $1.8 \%$ agarose gel, transferred to nylon membrane and hybridized to a $(\alpha-32 \mathrm{P})$-dCTP labelled erythropoietin receptor cDNA probe. ${ }^{20}$ Arrow indicates the position of expected $252 \mathrm{bp}$ fragment resulting from erythropoietin receptor amplification. The positions of the DNA size marker (base pairs) are indicated on the left $(\mathrm{M})$.

prostate cancer cell lines using immunoprecipitation (IP) and immunoblotting. Figure 3 illustrates the results of a representative experiment. As a positive control for IP, we used CHO cells engineered to stably express human erythropoietin receptor and observed expected $\sim 66 \mathrm{kDa}$ immunoreactivity consistent with erythropoietin receptor protein expression (Figure 3, lane 1) and as negative control, CHO cells transfected with empty expression vector were used where the IP and immunoblotting did not yield any immunoreactivity (Figure 3 lane 2). In immunoprecipitates of both LNCaP and PC-3 cells, we detected immunoreactivity consistent with erythropoietin receptor protein expression in prostate cancer cells (Figure 3, lanes 3 and 4, respectively).

In clinical tissue specimens of prostate cancer, we found the coexpression of erythropoietin receptor and its ligand erythropoietin. In the next set of experiments, we investigated whether erythropoietin mRNA transcripts are expressed in LNCaP and PC-3 prostate cancer cell lines. Total RNA isolated from the cells was subjected to reverse transcriptionpolymerase chain reaction as described in Materials 
IP: $\alpha$ EpoR

Blot: $\alpha$ EpoR

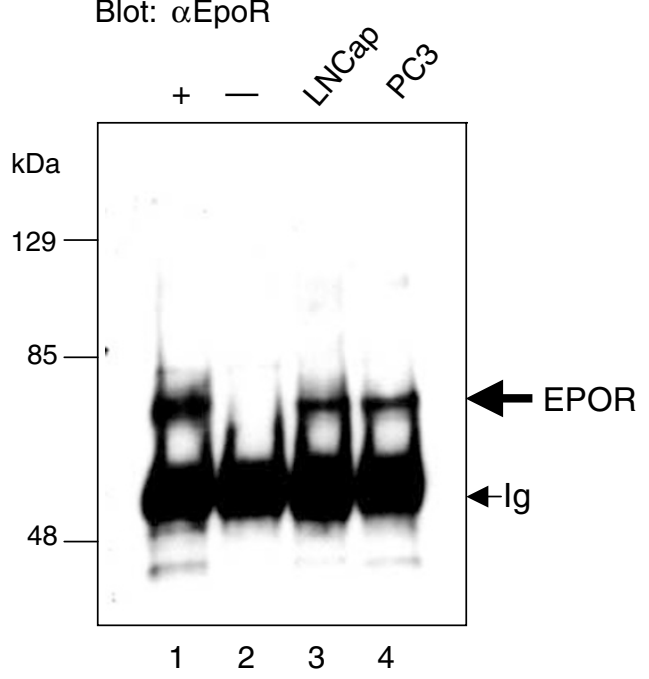

Figure 3 Expression of erythropoietin receptor protein in prostate cancer cells. Whole cell lysates from monolayer cultures of LNCaP and PC-3 cell lines were subjected to immunoprecipitation (IP) using erythropoietin receptor-specific antibody $(\alpha$ erythropoietin receptor) followed by Western blotting. Bold arrow indicates the position of $66 \mathrm{kDa}$ immunoreactive band illustrating erythropoietin receptor expression. Positive control (+) was CHO cells transfected with erythropoietin receptor expression vector and negative control (-) was CHO cells transfected with empty vector. Ig indicates immunoglobulin heavy chain of antibody used in IP. The positions of the molecular weight marker are illustrated on the left $(\mathrm{kDa})$.

and methods. The reverse transcription-polymerase chain reaction products were separated by agarose gel electrophoresis and Southern blotting was carried out followed by hybridization to a specific radiolabeled erythropoietin cDNA probe. Figure 4 illustrates the results of a representative experiment in which erythropoietin expression was observed in both LNCaP and PC-3 cells and positive control HepG2 cells (lanes 1, 3 and 5 respectively). Negative control reverse transcription-polymerase chain reactions were performed without reverse transcriptase and using water in the PCR (Figure 4, lanes 2, 4 and 6). Taken together, our studies demonstrate the expression of erythropoietin receptor and erythropoietin in prostate cancer cells.

\section{Discussion}

Prostate cancer is a major health problem with an estimated 230110 new cases and 29900 deaths expected in the United States during 2004. ${ }^{26}$ The majority of carcinomas that develop in the prostate are adenocarcinomas arising from the prostatic epithelium that initially occur as androgen-dependent tumors and often progress to tumors that are hormone-insensitive. Alterations in cellular androgen receptor expression or function have been implicated in prostate cancer progression. ${ }^{27,28}$ Pros- a

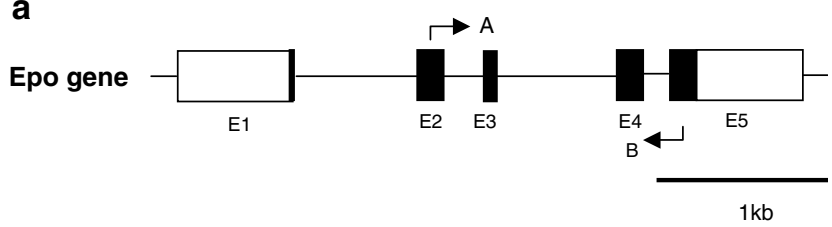

b

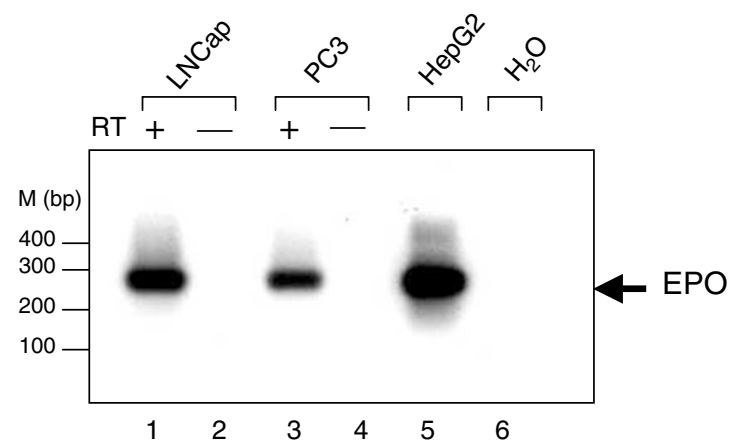

Figure 4 Expression of erythropoietin transcripts in monolayer cultures of prostate cancer cell lines. (a) The exon-intron structure of the erythropoietin gene is shown. The relative positions of the PCR primers A (sense) and B (antisense) are indicated in exons 2 and 5, respectively. (b) Reverse transcriptionpolymerase chain reaction was performed using RNA from monolayer cultures of prostate cancer cell lines LNCaP and PC3 (lanes 1 and 3). Negative controls included reverse transcription-polymerase chain reaction without reverse transcriptase in the reactions (reverse transcriptase -, lanes 2, 4), PCR using water $\left(\mathrm{H}_{2} \mathrm{O}\right.$, lane 6$)$ that did not yield amplification products. Positive control was reverse transcription-polymerase chain reaction using RNA from hepatoblastoma HepG2 cells (lane 5). The PCR amplification products were separated in $1.8 \%$ agarose gel, transferred to nylon membrane and hybridized to a $(\alpha-32 \mathrm{P})-$ dCTP-labeled erythropoietin cDNA probe. Arrow indicates the position of expected $279 \mathrm{bp}$ fragment resulting from erythropoietin amplification. The relative positions of the DNA size marker (basepairs) are shown on the left (M).

tate cancer cells also express nonsteroid cellular receptors which include transmembrane receptor protein tyrosine kinases such as the receptors for epidermal growth factor family and insulin-like growth factor. ${ }^{29-32}$ In the present study, we report the expression of the cytokine receptor erythropoietin receptor and its ligand the glycoprotein hormone erythropoietin in human prostate cancer cells.

The ability of erythropoietin to stimulate the production of red blood cells has led to the use of recombinant human erythropoietin for the prevention or treatment of anemia in cancer patients. ${ }^{33}$ The benefits of recombinant human erythropoietin in patients with cancer-related anemia include increased hemoglobin levels, reduced transfusion requirements and improved quality of life. ${ }^{34-38}$ In patients with prostate cancer, the presence of anemia may be associated with a significant reduction in survival. ${ }^{39}$ In patients with hormone-refractory prostate cancer, serial measurements of hemoglobin provided as much, or more prognostic information as serial measurement of PSA. ${ }^{40}$ Anemia was reported to develop in $81 \%$ of patients with prostate cancer after receiving neoadjuvant 
combined androgen blockade and pelvic radiotherapy. ${ }^{41}$ In another study, combined hormonal blockade was associated with a significant decrease in hemoglobin in $90 \%$ of patients; this decline was related to the duration of treatment and recovered after treatment of symptomatic patients with recombinant human erythropoietin. ${ }^{42}$ In a randomized study of patients with anemia and metastatic hormone-refractory prostate cancer, administration of higher doses of recombinant human erythropoietin was associated with increased hemoglobin, reduction of blood transfusions and improvement in quality of life compared to lower erythropoietin doses. ${ }^{43}$ In another randomized study of anemic cancer patients, including those with prostate cancer undergoing radiotherapy, recombinant human erythropoietin administration was associated with a beneficial effect on hemoglobin levels. ${ }^{44}$ It has been suggested in the literature that in patients with prostate cancer, recombinant human erythropoietin use may be justified prior to radical prostatectomy to reduce autologous blood transfusion risk as well as in anemic patients with advanced, hormone-refractory disease. ${ }^{45,46}$ However, in light of our findings, in patients with prostate cancer who may benefit from therapy with recombinant human erythropoietin, the expression of erythropoietin receptor in tumor cells may need to be taken into consideration in the design of future clinical trials.

Erythropoietin exerts its cellular effects by binding to its specific transmembrane receptor, the erythropoietin receptor, a member of the Type I cytokine receptor superfamily, characterized by the absence of intrinsic tyrosine kinase enzymatic activity. ${ }^{47,48}$ Expression of members of the cytokine receptor family other than erythropoietin receptor were previously reported in prostate cancer cells, such as the receptors for interleukin- $6^{49-51}$ and granulocyte-macrophage colony stimulating factor. ${ }^{52,53}$ Interleukin-6 has been shown to contribute to the growth of prostate cancer cells as an autocrine and paracrine factor ${ }^{51}$ and to the activation of androgen receptor-dependent gene expression. ${ }^{54}$ Similarly, recombinant human granulocyte-macrophage colony stimulating factor was found to stimulate the proliferation of LNCaP cells. ${ }^{53}$ Whether or not erythropoietin may contribute to the growth of prostate cancer cells in a manner similar to interleukin-6 or granulocyte-macrophage colony stimulating factor remains to be determined. The coexpression of erythropoietin receptor and its ligand erythropoietin in prostate cancer cells suggests the potential for an autocrine and/or paracrine growth-promoting role for erythropoietin-erythropoietin receptor in prostate cancer.

Several recent studies from our laboratory as well as others have reported the expression of erythropoietin receptor and, in some cases erythropoietin, in primary neoplasms and tumor cell lines such as melanoma, breast, renal, ovarian, gastric and uterine cancers as well as pediatric tumors. ${ }^{18-20,24,55-62}$ In experimental animal models of cancer, disruption of erythropoietin-erythropoietin receptor signaling in tumors was associated with an antitumor effect in xenografts of human female genital tract cancers and melanoma ${ }^{58,61}$ and in a rodent syngeneic model of breast cancer. ${ }^{19}$ The pathophysiologic role, if any, of erythropoietin receptor and erythropoietin coexpression in prostate cancer cells and whether exogenous recombinant erythropoietin may exert direct in vivo effects on tumor cells that express erythropoietin receptor remain to be determined. Our studies have shown the expression of erythropoietin receptor in monolayer cultures of hormonesensitive (LNCaP) and hormone-refractory (PC-3) cancer cell lines derived from human prostate cancer. These prostate cancer cell lines may be useful for future in vitro and in vivo studies of erythropoietin-erythropoietin receptor function in prostate cancer.

The efficacy and safety of recombinant human erythropoietin in cancer patients has been demonstrated in several randomized clinical trials involving large numbers of patients. ${ }^{38,63,64}$ However, a randomized, prospective trial involving patients with metastatic breast cancer was terminated early due to impaired survival associated with disease progression in the recombinant erythropoietin arm compared to the placebo arm. ${ }^{65}$ In another trial of patients with head neck cancer receiving radiation therapy only, poorer progression-free survival was reported in patients randomized to the recombinant human erythropoietin arm. ${ }^{66}$ Given the results of our studies demonstrating the expression of erythropoietin receptor and its ligand erythropoietin in prostate cancer cells, further investigations of the biology of erythropoietin-erythropoietin receptor in prostate cancer are warranted.

\section{Acknowledgements}

This study was supported in part by NIH Grants DK-02566 (MOA) and CA-62215 (WDW) of the Committee for Urologic Research, Education and Development (CURED) at Duke University Medical Center.

\section{References}

1 Krantz SB. Erythropoietin. Blood 1991;77:419-434.

2 Ebert BL, Bunn HF. Regulation of the erythropoietin gene. Blood 1999;94:1864-1877.

3 Henry DH. Guidelines for the use of epoetin in cancer patients: a much-needed step forward in standardizing anemia treatment. Blood 2003;102:2697-2698.

4 D'Andrea AD, Lodish HF, Wong GG. Expression cloning of the murine erythropoietin receptor. Cell 1989;57:277-285. 
5 Jones SS, D'Andrea AD, Haines LL, et al. Human erythropoietin receptor: cloning, expression, and biologic characterization. Blood 1990;76:31-35.

6 Winkelmann JC, Penny LA, Deaven LL, et al. The gene for the human erythropoietin receptor: analysis of the coding sequence and assignment to chromosome 19p. Blood 1990;76:24-30.

7 Livnah O, Stura EA, Middleton SA, et al. Crystallographic evidence for preformed dimers of erythropoietin receptor before ligand activation. Science 1999;283:987-990.

8 Remy I, Wilson IA, Michnick SW. Erythropoietin receptor activation by a ligand-induced conformation change. Science 1999;283:990-993.

9 Anagnostou A, Lee ES, Kessimian N, et al. Erythropoietin has a mitogenic and positive chemotactic effect on endothelial cells. Proc Natl Acad Sci USA 1990;87:5978-5982.

10 Anagnostou A, Liu Z, Steiner M, et al. Erythropoietin receptor mRNA expression in human endothelial cells. Proc Natl Acad Sci USA 1994;91:3974-3978.

11 Masuda S, Nagao M, Takahata K, et al. Functional erythropoietin receptor of the cells with neural characteristics. Comparison with receptor properties of erythroid cells. J Biol Chem 1993;268:1120811216.

12 Masuda S, Okano M, Yamagishi K, et al. A novel site of erythropoietin production. Oxygen-dependent production in cultured rat astrocytes. J Biol Chem 1994;269: 19488-19493.

13 Digicaylioglu M, Bichet S, Marti HH, et al. Localization of specific erythropoietin binding sites in defined areas of the mouse brain. Proc Natl Acad Sci USA 1995;92:3717-3720.

14 Sakanaka M, Wen TC, Matsuda S, et al. In vivo evidence that erythropoietin protects neurons from ischemic damage. Proc Natl Acad Sci USA 1998;95: 4635-4640.

15 Digicaylioglu M, Lipton SA. Erythropoietin-mediated neuroprotection involves cross-talk between Jak2 and NF-kappaB signalling cascades. Nature 2001;412: 641-647.

16 Yasuda Y, Masuda S, Chikuma M, et al. Estrogendependent production of erythropoietin in uterus and its implication in uterine angiogenesis. J Biol Chem 1998;273:25381-25387.

17 Haroon ZA, Amin K, Jiang X, et al. A novel role for erythropoietin during fibrin-induced wound-healing response. Am J Pathol 2003;163:993-1000.

18 Acs G, Zhang PJ, Rebbeck TR, et al. Immunohistochemical expression of erythropoietin and erythropoietin receptor in breast carcinoma. Cancer 2002;95: 969-981.

19 Arcasoy MO, Amin K, Karayal AF, et al. Functional significance of erythropoietin receptor expression in breast cancer. Lab Invest 2002;82:911-918.

20 Arcasoy MO, Jiang X, Haroon ZA. Expression of erythropoietin receptor splice variants in human cancer. Biochem Biophys Res Commun 2003;307: 999-1007.

21 Fairchild Benyo D, Conrad KP. Expression of the erythropoietin receptor by trophoblast cellsin the human placenta. Biol Reprod 1999;60:861-870.

22 Juul SE, Yachnis AT, Christensen RD. Tissue distribution of erythropoietin and erythropoietin receptor in the developing human fetus. Early Hum Dev 1998;52: 235-249.
23 Demark-Wahnefried W, Price DT, Polascik TJ, et al. Pilot study of dietary fat restriction and flaxseed supplementation in men with prostate cancer before surgery: exploring the effects on hormonal levels, prostate-specific antigen, and histopathologic features. Urology 2001;58:47-52.

24 Acs G, Acs P, Beckwith SM, et al. Erythropoietin and erythropoietin receptor expression in human cancer. Cancer Res 2001;61:3561-3565.

25 Acs G, Zhang PJ, McGrath CM, et al. Hypoxiainducible erythropoietin signaling in squamous dysplasia and squamous cell carcinoma of the uterine cervix and its potential role in cervical carcinogenesis and tumor progression. Am J Pathol 2003;162: 1789-1806.

26 American Cancer Society. Cancer Facts Figures 2004;16.

27 Gaddipati JP, McLeod DG, Heidenberg HB, et al. Frequent detection of codon 877 mutation in the androgen receptor gene in advanced prostate cancers. Cancer Res 1994;54:2861-2864.

28 Visakorpi $\mathrm{T}$, Hyytinen E, Koivisto $\mathrm{P}$, et al. In vivo amplification of the androgen receptor gene and progression of human prostate cancer. Nat Genet 1995;9:

401-406.

29 Iwamura M, Sluss PM, Casamento JB, et al. Insulin-like growth factor I: action and receptor characterization in human prostate cancer cell lines. Prostate 1993;22: 243-252.

30 Culig Z, Hobisch A, Cronauer MV, et al. Androgen receptor activation in prostatic tumor cell lines by insulin-like growth factor-I, keratinocyte growth factor, and epidermal growth factor. Cancer Res 1994;54: 5474-5478.

31 Hellawell GO, Turner GD, Davies DR, et al. Expression of the type 1 insulin-like growth factor receptor is upregulated in primary prostate cancer and commonly persists in metastatic disease. Cancer Res 2002;62: 2942-2950.

32 Hernes E, Fossa SD, Berner A, et al. Expression of the epidermal growth factor receptor family in prostate carcinoma before and during androgen-independence. Br J Cancer 2004;90:449-454.

33 Rizzo JD, Lichtin AE, Woolf SH, et al. Use of epoetin in patients with cancer: evidence-based clinical practice guidelines of the American Society of Clinical Oncology and the American Society of Hematology. Blood 2002;100:2303-2320.

34 Glaspy J, Bukowski R, Steinberg D, et al. Impact of therapy with epoetin alfa on clinical outcomes in patients with nonmyeloid malignancies during cancer chemotherapy in community oncology practice. Procrit Study Group. J Clin Oncol 1997;15: 1218-1234.

35 Demetri GD, Kris M, Wade J, et al. Quality-of-life benefit in chemotherapy patients treated with epoetin alfa is independent of disease response or tumor type: results from a prospective community oncology study. Procrit Study Group. J Clin Oncol 1998;16: 3412-3425.

36 Gabrilove JL, Cleeland CS, Livingston RB, et al. Clinical evaluation of once-weekly dosing of epoetin alfa in chemotherapy patients: improvements in hemoglobin and quality of life are similar to threetimes-weekly dosing. J Clin Oncol 2001;19: $2875-2882$. 
37 Quirt I, Robeson C, Lau CY, et al. Epoetin alfa therapy increases hemoglobin levels and improves quality of life in patients with cancer-related anemia who are not receiving chemotherapy and patients with anemia who are receiving chemotherapy. J Clin Oncol 2001;19: 4126-4134.

38 Littlewood TJ, Bajetta E, Nortier JW, et al. Effects of epoetin alfa on hematologic parameters and quality of life in cancer patients receiving nonplatinum chemotherapy: results of a randomized, doubleblind, placebo-controlled trial. J Clin Oncol 2001;19: 2865-2874.

39 Caro JJ, Salas M, Ward A, et al. Anemia as an independent prognostic factor for survival in patients with cancer: a systemic, quantitative review. Cancer 2001;91:2214-2221.

40 Vollmer RT, Kantoff PW, Dawson NA, et al. Importance of serum hemoglobin in hormone refractory prostate cancer. Clin Cancer Res 2002;8:1049-1053.

41 Asbell SO, Leon SA, Tester WJ, et al. Development of anemia and recovery in prostate cancer patients treated with combined androgen blockade and radiotherapy. Prostate 1996;29:243-248.

42 Strum SB, McDermed JE, Scholz MC, et al. Anaemia associated with androgen deprivation in patients with prostate cancer receiving combined hormone blockade. Br J Urol 1997;79:933-941.

43 Johansson JE, Wersall P, Brandberg Y, et al. Efficacy of epoetin beta on hemoglobin, quality of life, and transfusion needs in patients with anemia due to hormone-refractory prostate cancer-a randomized study. Scand J Urol Nephrol 2001;35:288-294.

44 Sweeney PJ, Nicolae D, Ignacio L, et al. Effect of subcutaneous recombinant human erythropoietin in cancer patients receiving radiotherapy: final report of a randomized, open-labelled, phase II trial. Br J Cancer 1998;77:1996-2002.

45 Beshara S, Letocha $\mathrm{H}$, Linde $\mathrm{T}$, et al. Anemia associated with advanced prostatic adenocarcinoma: effects of recombinant human erythropoietin. Prostate 1997;31:153-160.

46 Albers P, Heicappell R, Schwaibold H, et al. Erythropoietin in urologic oncology. Eur Urol 2001;39:1-8.

47 Bazan JF. Structural design and molecular evolution of a cytokine receptor superfamily. Proc Natl Acad Sci USA 1990;87:6934-6938.

48 D'Andrea AD, Fasman GD, Lodish HF. A new hematopoietic growth factor receptor superfamily: structural features and implications for signal transduction. Curr Opin Cell Biol 1990;2:648-651.

49 Siegall CB, Schwab G, Nordan RP, et al. Expression of the interleukin 6 receptor and interleukin 6 in prostate carcinoma cells. Cancer Res 1990;50:7786-7788.

50 Siegsmund MJ, Yamazaki H, Pastan I. Interleukin 6 receptor mRNA in prostate carcinomas and benign prostate hyperplasia. J Urol 1994;151:1396-1399.

51 Okamoto M, Lee C, Oyasu R. Interleukin-6 as a paracrine and autocrine growth factor in human prostatic carcinoma cells in vitro. Cancer Res 1997;57:141-146.

52 Lang SH, Miller WR, Duncan W, et al. Production and response of human prostate cancer cell lines to granulocyte macrophage-colony stimulating factor. Int J Cancer 1994;59:235-241.

53 Rivas CI, Vera JC, Delgado-Lopez F, et al. Expression of granulocyte-macrophage colony-stimulating factor receptors in human prostate cancer. Blood 1998;91:1037-1043.

54 Hobisch A, Eder IE, Putz T, et al. Interleukin-6 regulates prostate-specific protein expression in prostate carcinoma cells by activation of the androgen receptor. Cancer Res 1998;58:4640-4645.

55 Selzer E, Wacheck V, Kodym R, et al. Erythropoietin receptor expression in human melanoma cells. Melanoma Res 2000;10:421-426.

56 Westenfelder C, Baranowski RL. Erythropoietin stimulates proliferation of human renal carcinoma cells. Kidney Int 2000;58:647-657.

57 Westphal G, Niederberger E, Blum C, et al. Erythropoietin and G-CSF receptors in human tumor cells: expression and aspects regarding functionality. Tumori 2002;88:150-159.

58 Yasuda Y, Musha T, Tanaka H, et al. Inhibition of erythropoietin signalling destroys xenografts of ovarian and uterine cancers in nude mice. $\mathrm{Br} \mathrm{J}$ Cancer 2001;84:836-843.

59 Yasuda Y, Fujita Y, Masuda S, et al. Erythropoietin is involved in growth and angiogenesis in malignant tumours of female reproductive organs. Carcinogenesis 2002;23:1797-1805.

60 Ribatti D, Marzullo A, Nico B, et al. Erythropoietin as an angiogenic factor in gastric carcinoma. Histopathology 2003;42:246-250.

61 Yasuda Y, Fujita Y, Matsuo T, et al. Erythropoietin regulates tumour growth of human malignancies. Carcinogenesis 2003;24:1021-1029.

62 Batra S, Perelman N, Luck LR, et al. Pediatric tumor cells express erythropoietin and a functional erythropoietin receptor that promotes angiogenesis and tumor cell survival. Lab Invest 2003;83:1477-1487.

63 Abels RI. Recombinant human erythropoietin in the treatment of the anaemia of cancer. Acta Haematol 1992;87(Suppl 1): 4-11.

64 Fallowfield L, Gagnon D, Zagari M, et al. Multivariate regression analyses of data from a randomised, doubleblind, placebo-controlled study confirm quality of life benefit of epoetin alfa in patients receiving non-platinum chemotherapy. Br J Cancer 2002;87: 1341-1353.

65 Leyland-Jones B. Breast cancer trial with erythropoietin terminated unexpectedly. Lancet Oncol 2003;4:459-460.

66 Henke M, Laszig R, Rube C, et al. Erythropoietin to treat head and neck cancer patients with anaemia undergoing radiotherapy: randomised, double-blind, placebo-controlled trial. Lancet 2003;362:1255-1260. 